Journal of Entrepreneurship \& Project Management

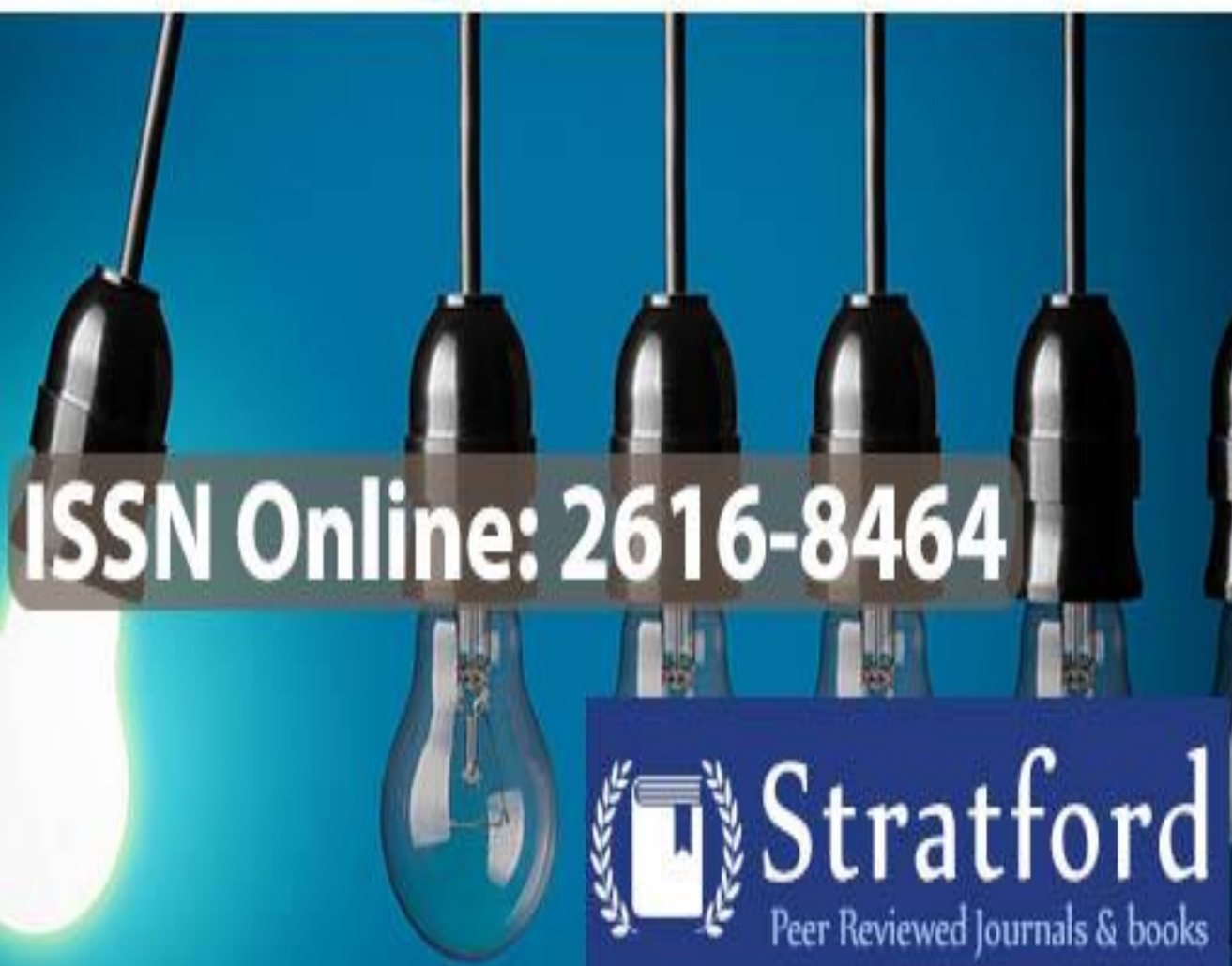

Construction Delays and Project Cost Overrun A Case of Regional Cybercrime Center in Gasabo District, Rwanda

Mr. Franklin S. Amanya \& Dr. Gitahi Njenga

ISSN: 2616-8464 


\title{
Construction Delays and Project Cost Overrun: A Case of Regional Cybercrime Center in Gasabo District, Rwanda
}

\author{
${ }^{* 1}$ Mr. Franklin S.Amanya \& ${ }^{2}$ Dr. Gitahi Njenga \\ ${ }^{*}$ School of Business and Economics, Master of Business Administration (MBA), Project \\ Management, Mount Kenya University, Kigali, Rwanda \\ ${ }^{2}$ Mount Kenya University, Kigali, Rwanda
}

How to cite this article: Amanya, F, S. \& Njenga, G. (2022). Construction Delays and Project Cost Overrun: A Case of Regional Cybercrime Center in Gasabo District, Rwanda. Journal of Entrepreneurship \& Project Management. Vol 6(1) pp. 34-52. https://doi.org/10.53819/81018102t2049

\begin{abstract}
The aim of the survey was to understand the relationship between construction delays and cost overrun in Rwanda more specifically in the Regional Cybercrime Center. More specifically, the research addressed the specific objectives of the effect of inexcusable delays, effect of non-compensable delays and examined the effect of compensable delays on the cost overrun of construction of Regional Cybercrime Center. This survey was anchored on the Stakeholder theory and Results Based Management theory. A combination of descriptive and correlation design was used in this study. A population of 45 including procurement officers, logistic officers, budgeting officers, project managers, site engineers, project planners, interior designers, architectures, it managers, it technicians, supervisors and communication technicians in charge of activities regarding construction and other related activities of Regional Cybercrime Center were used. This study adopted a consensus approach and encompassed the whole population as sample size. Questionnaires were distributed and used in collection of data. The questionnaires were tested for validity and reliability and a Cronbach's Alpha of over 0.70 was recorded. Information analysis encompassed the adoption of descriptive statistics by use of standard deviation and mean while inferential statistics were done using correlation and regression and the findings presented using tables and figures. The findings showed Pearson correlation of 0.773 between inexcusable delays and cost overrun while adjusted R-square of 0.588 showed moderating effect and also analysis of variance found to be significant at less than 0.005 . For the correlation coefficient of 0.657 between non-compensable delays and cost overrun while adjusted R-square of 0.418 showed weak effect and also analysis of variance found to be significant. For the correlation coefficient of 0.799 between compensable delays and cost overrun though adjusted R-square of 0.630 showed moderating effect and also analysis of variance found to be significant. From outcomes, the objectives were achieved and the entire null hypotheses were rejected. For project owners to achieve timely completion of construction projects without having to incur extra costs which lead to project cost overruns, financial resources/project budget necessary to execute the project must be fully committed and set aside to avoid incongruities caused by delay in payments.
\end{abstract}

Keywords: Construction delays, cost overrun, regional cybercrime center, Rwanda 


\section{Introduction}

In spite of the interventions by Government of Rwanda in private sector for supporting construction projects, most areas in Rwanda are marred by projects that are delayed, disrupted, and uncompleted. Explanations for the stages of each building project vary and are sometimes attributed to poor financial muscle, lack of human and material resources with which to execute the projects. During the period 2012-2015, 65.7 percent of public construction projects in just one district of Rwanda were delayed. Another example is the Kigali Convention Center, originally scheduled to open in 2011, but was postponed until 2016. The construction of Bugesera International Airport is yet another illustration, it was supposed to be completed by the year 2016, nonetheless has yet to break ground (Ndundo \& Mbabazi, 2016). A construction project analysis carried out in order to review the primary reasons for delays in Rwanda. In accordance with statistical analysis of 15 commercial building projects completed between 2010 and 2020, none of them met planned project schedule. It was discovered that $15 \%$ of these projects were canceled, and $75 \%$ required more time to be completed (Chandu \& Bhalerao, 2016).

Samson (2016) identified and analyzed the sources of delays for some selected construction projects in Kigali city; among them $45 \%$ are due to time overruns, 33.4\% cost overruns, 21.6 $\%$ disputes. According to findings by Samson (2016), Ndundo and Mbabazi (2016), Chandu and Bhalerao (2016) all conducted studies on construction project delays and cost overruns in Rwanda showed that, construction delays continue to manifest almost in all construction projects. Statistics from One Stop Center for Construction projects in the City of Kigali indicate that over $69 \%$ of construction projects issued with construction permits requests for extension of the project schedule. After analyzing the published studies on the topic, investigators failed to discover a similar focused study on the effect of each type of delay including inexcusable, non-compensable and compensable delays on cost overrun of projects, indicating a gap that must be filed. As such, this research tackled on assessing the relationship between delays and cost overrun in construction projects in Rwanda more specifically at the Regional Cybercrime Center.

\subsection{Objectives of the study}

\subsubsection{General objective}

The general objective of this research was to examine the relationship between construction delays and project cost overruns in Rwanda more specifically at the Regional Cybercrime Centre.

\subsubsection{Specific Objectives}

The specific objectives are the following.

(i) To assess the effect of inexcusable delays on the cost overrun of construction of Regional Cybercrime Center in Gasabo District, Rwanda.

(ii) To examine the results of non-compensable delays on the cost overrun of construction of Regional Cybercrime Center in Gasabo District, Rwanda.

(iii) To assess the results of compensable delays on the cost overrun of construction of Regional Cybercrime Center in Gasabo District, Rwanda. 


\subsubsection{Research Hypotheses}

$\mathbf{H}_{01}$ : Inexcusable delays have no statistically significant effect on cost overrun of construction of Regional Cybercrime Center in Gasabo District, Rwanda.

$\mathbf{H}_{\mathbf{0 2}}$ : Non-compensable delays have no statistically significant impact on the additional building costs of the Regional Cybercrime Center in Gasabo District, Rwanda.

$\mathbf{H}_{03}$ : Compensable delays have no statistically significant effect on cost overrun of construction of Regional Cybercrime Center in Gasabo District, Rwanda.

\subsection{Empirical Literature Review}

\subsubsection{Inexcusable delays and cost overrun}

The most significant critical delay causes for consultants, according to the findings of this study, are contactor's poor project planning and timing, as well as contractor's financial troubles and an excessive number of change orders from the owner. In the case of contractors, it was discovered that financial difficulties were followed by a change in order by the owners and a shortage of manpower. The owners, on the other hand, experienced delays due to inadequate planning and scheduling by contractors, monetary difficulties encountered by contractors, and unskilled labor. The author concluded that the most influential factor is contractor-related, followed by the owner's excessive order changes (Sweis \& Shiboul, 2008). Singh (2010) investigated project delays and cost escalation in 894 projects across 17 infrastructure sectors. Delays, according to this study, are a major cause of cost overruns. Larger projects have had far greater cost overruns when in comparison to smaller projects. According to Saleh and Abdul (2009), construction delays are a critical component of construction projects and among the serious issues confronting Libyan construction firms. The contractor's factors that contribute to delay were ranked in this study using the mean value criteria. Additionally, they identified the consequences of construction project delays, including authority blacklisting, stakeholder disengagement, reputational damage, financial and time waste.

According to Remon (2013), this research identified, examined, and prioritized perceived factors affecting construction project delays and proposed potential solutions to this phenomenon. Several factors were identified and classified as part of the questionnaire survey, including contractor factors, design, consultant, equipment, laboratory, external, material and proprietor factors. Towhid and Amiruddin (2012) stated that, over the last decade, delays in the field of construction have been reviewed via a questionnaire poll in Iran to extract the reasons for the delays from consultants and contractors' views. Another study conducted by Kwatsima (2015) discovered that, the top factors causing delays, in order of importance, were: delays in honoring certificates, a shortage of experienced contractors for large projects, design changes, a lack of professional project management skills in construction projects, and a shortage of skilled tradesmen to collaborate with new construction technology (Kwatsima, 2015). It has been determined that there are ten significant delay factors that contribute to construction delays. These include; insufficient cash flow, delays in payment, lack of communication among parties, contract time underestimation, insufficient supervision, instruction delays, variation, insufficient skill, insufficient professional management, inexperienced contactor staff and poor site management. The author proposed several strategies, the most effective of which are engaging competent consultants, having a clear vision during the design and planning stages, closely supervising the work by all parties, involving financially stable contactors, hiring staff 
with demonstrated competence, effective communication flow, timely payment, holding regular site meetings and prompt decision making (Henry \& Henry, 2013).

\subsubsection{Non compensable delays and cost overrun}

Numerous reviews and surveys done to clarify on the main source of cost overruns sometimes referred to as "cost overruns" in building construction-projects. Cost overruns were primarily triggered by material cost increase, material take-off and cost increases as result of environmental constraints. Cost overruns in Vietnam are often caused by three factors: labor costs, erroneous quantity take-off, and material cost increases owing to environmental limits. (Le-Hoai \& Lee, 2008).

Non-compensable delays are resulted from non-contractual sides or occurrences out of management of contracting parties and are not attributable to either party (Fugar \& Agyakwah, 2010). Examples include acts of God, weather conditions, strikes, fires, and actions of government acting in its sovereign role. In this case, the contractor is usually entitled to a time extension but not to compensation for delays (Soon, 2010). According to Kaliba (2009), a variety of variables contribute to cost inflation in Zambian building projects, including weather conditions, alternations in scope, protection of environment, mitigation costs, delays in schedule, strikes, practical difficulties, and inflation. Weather effects, the number of concurrent projects, Impacts on society and culture, project site, and Saudi Arabia's insufficient productivity standards, competiveness level, manipulation of supplier, stability of economy, and insufficient raw material production by the telecommunications industry were identified as factors contributing to cost overruns on Saudi Arabian construction projects (Bubshait \& Al-Juwait, 2002).

\subsubsection{Compensable delays and cost overrun}

Enas and Pandey (2013) during planning and design, the sources of delays were emphasized. Engineers working on public construction projects in India were handed a standardized questionnaire. The relative relevance index was employed in this research to determine the reasons of delays, as well as their size and frequency. Client demand changes are the most common source of project delays during planning and design. Project delays caused by clients, contractors, labor and materials were identified. Findings showed that managing and controlling these causes can reduce delays.According to Kasimu (2012), the study focuses on specific causes of construction projects delays such as insufficient coordination and improper communication between involved parties. This study was conducted using questionnaires for info gathering. The outcomes were checked using standard deviation and mean. Which show factors such as poor activity scheduling, inappropriate communication and design as some of the causes of construction project delays.

Amandin and Kule (2016) an open-ended questionnaire was used to analyze delays and cost overrun concerns in Gasabo District, one of Rwanda's 30 districts. From 2012 to 2019, they determined the top five causes for public construction project delays. Experienced delays in payment, material procurement, poor supervision, financial constraints on the part of client and contactors. Meanwhile, in their study about determinants of cost overrun in Rwandan construction projects, Gasasira, Peter and Eugene (2016) found that poor cost estimation, poor design, poor schedule management, slow decision making, problem in land acquisition poor contract management, delay in providing design and the primary reasons were a lack of soil investigation.

Delay in payment was the sole factor for the proprietor recorded in the top 10. This shows that once the contract indicates a payment plan there is no any delay in payment. It was also requested that before the execution of the project, the owner should avail enough funds for 
construction activities. The effects of ground conditions and land acquisition on the project must be thoroughly managed and assessed in order to minimize their effects on the three project objectives. Hiring a competent external specialist provide an accurate assessment of the affected community's land value when acquiring land for road projects (Santoso, 2012).

\subsection{Research Gap}

Previous surveys focused on the elements that led to project overruns in the budget in developed and developing nations' building. According to Remon (2013), this research work attempts to investigate, identify and rank the factors to affect construction project delays in terms of their relative importance in order to propose possible solutions to this phenomenon. Towhid and Amiruddin (2012) stated that over the last decade, the field of construction project delays has been reviewed via a survey carried out in Iranian to provoke the reasons of delays from contractors and counselors.

According to Le-Hoai (2008), the most 3 often sources of cost overruns are imprecise diminution in quantity, inflation as well as work price increase from environmental constraints. According to Kaliba (2009), cost boom in Zambian constructions tasks is due to variety causes including scope changes, bad storm, schedule delays, inflation, protection of environment, strikes, inflation besides technical challenges. According to Kasimu (2013), the survey centered on unique source of construction project delays such as insufficient coordination and improper communication between involved parties. Amandin and Kule (2016) researched on cost overruns risks using an open-ended questionnaire, initiatives were carried out in Gasabo District, one of Rwanda's 30 districts. They determined that, late payments were among the top 5 causes for public construction project delays from 2012 to 2019, inadequate material procurement, derisory supervision and financial snags on the part of both contactor and client.

In summary, many researches have been carried out on the delays and cost overruns in building projects, but no studies have been conducted on Inexcusable, controllable and noncompensable delays on project cost overruns. However, when the characteristics of building projects were taken into account, the results were quite different. Most studies conducted in Rwanda focused on the reasons for delays and source of project cost overruns in general rather than on specific delay of construction projects. In Rwanda, no research has been done on the effects of construction delays on project cost overruns with the same specific aims. The goal is to supplement on understanding of delays and cost overruns in construction domain. The researcher found more answers that augment the existing literature as well as uncovered reasons for the delays of construction projects in Rwanda.

\subsection{Conceptual Framework}

The conceptual framework is utilized in this study to describe the key ideas or variables that need to be explored, as well as the relationships that occur between them. Simply said, a conceptual framework is the way ideas are structured to achieve a research study's purpose, and explanation is the most common method for accomplish this goal. Independent variables of this study including inexcusable delays, non-compensable delays and compensable delays how they are linked with dependent variable namely cost overrun. For the side of inexcusable delays there are indicators of inadequate contactor experience, subcontractor related problems and poor project implementation. As the first objective of the study assess how those indicators may affect cost overrun indicated by underestimate cost, changes in input prices and changes in design and execution. Non compensable delays have indicators of natural disasters, unfavorable weather and pandemics / emergencies. as the second objective of the study assess how those indicators may affect cost overrun indicated by underestimate cost, 
changes in input prices and changes in design and execution while compensable delays have indicators of changing of design and scope by clients, many stakeholders and owner's architect drawings late release. The third objective of the study assessed how these indicators affect cost overrun which revealed among other causes to be largely a result of underestimation of cost, changes in input prices and changes in design and execution. Intervening variable which is government policy also affected surplus of cost of the Regional Cybercrime Center as it meant change of the modus operandi to meet the new set policies which were not catered for at the initial stage.

\section{Independent Variable (Delays)}

\section{Inexcusable delays}

Inadequate contactor experience

Subcontractor related problems

Poor project implementation

\section{Non-compensable delays \\ Natural disasters \\ Unfavorable weather \\ Pandemics / Emergencies}

Compensable delays

Changing of design and scope by clients

Many stakeholders

Delayed drawings

\section{Dependent variable}

(Cost Overrun)

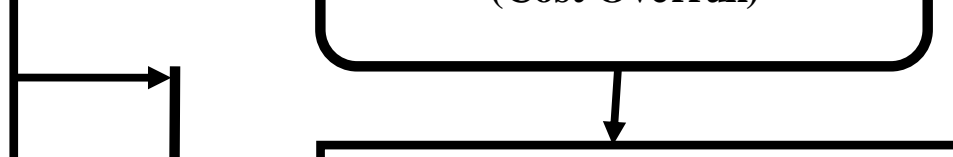

\section{Cost overrun}

Lack of proper cost management

Poor material management

Inefficient project design

Intervening variable

Government policy

Source: Research, 2022

Figure 2.1: Conceptual Framework

The Figure 2.1 demonstrates the relationship between the independent variable known as delays with the dependent variable known as cost overrun. The project delays is measured by inexcusable, non-compensable and compensable delays that has different metrics as shown in the figure 2.1 whereas cost overrun is measured by lack of proper cost management, poor material management and inefficient project design. Lastly, there is an intervening variable which is government policy and it can affect the relationship by cause a change in cost overrun.

\section{Materials and Methods}

This research has used a combination of descriptive and correlation designs. Descriptive survey research designs are appropriate for assessing associations or relationships between things and the resulting data can be used to provide a causal explanation for phenomena. The relationship between independent and dependent variables was explained using correlation design. A population of 45 was considered where in which the researcher used census method 
to select the whole target population as the sample size of 45 respondents including procurement officers, logistic officers, budgeting officers, project managers, site engineers, project planners, interior designers, architectures, it managers, it technicians, supervisors and communication technicians in charge of activities regarding construction and other related activities of Regional Cybercrime Center were used. Questionnaires were distributed and used in collection of data. The questionnaires were tested for validity and reliability and a Cronbach's Alpha of over 0.70 was recorded.

Data analysis encompassed the adoption of descriptive statistics by use of standard deviation and mean while inferential statistics were done using correlation and regression and the findings presented using tables. The regression analysis model was used; $Y=\beta 0+\beta 1 \mathrm{X} 1+\beta 2$ $\mathrm{X} 2+\beta 3 \mathrm{X} 3+\varepsilon ; \mathrm{Y}$ is Cost overrun, $\beta 0$ is a constant coefficient of determination, $\beta 1$ to $\beta 3$ are coefficients of determination to their respective predictors, $\mathrm{X} 1$ is the of inexcusable delays, $\mathrm{X} 2$ is the non-compensable delays, $\mathrm{X} 3$ is compensable delays.

\section{Research Findings and discussion}

4.2.1 Findings and discussion on Inexcusable delays and project cost overrun Table 1: Respondents views on factors of Inexcusable delays in Regional Cybercrime Center

\begin{tabular}{|c|c|c|c|c|c|c|c|}
\hline Statement & $\begin{array}{c}\text { Strongly } \\
\text { Agree (5) }\end{array}$ & $\begin{array}{l}\text { Agree } \\
\text { (4) }\end{array}$ & $\begin{array}{c}\text { Neutral } \\
\text { (3) }\end{array}$ & $\begin{array}{l}\text { Disagree } \\
\text { (2) }\end{array}$ & $\begin{array}{l}\text { Strongly } \\
\text { Disagree } \\
\text { (1) } \\
\end{array}$ & Mean & $\begin{array}{l}\text { Std. } \\
\text { Dev. }\end{array}$ \\
\hline $\begin{array}{l}\text { Delays in production of } \\
\text { workshop drawings and } \\
\text { sample tools }\end{array}$ & $\begin{array}{c}20 \\
(44.4 \%)\end{array}$ & $\begin{array}{c}14 \\
(31.1 \%)\end{array}$ & $\begin{array}{c}4 \\
(8.9 \%)\end{array}$ & $\begin{array}{c}4 \\
(8.9 \%)\end{array}$ & $\begin{array}{c}3 \\
(6.7 \%)\end{array}$ & 3.97 & 1.23 \\
\hline $\begin{array}{l}\text { Lack of cooperation and } \\
\text { communication in } \\
\text { concerning parties }\end{array}$ & $\begin{array}{c}19 \\
(42.2 \%)\end{array}$ & $\begin{array}{c}18 \\
(40.0 \%)\end{array}$ & $\begin{array}{c}3 \\
(6.7 \%)\end{array}$ & $\begin{array}{c}4 \\
(8.9 \%)\end{array}$ & $\begin{array}{c}1 \\
(2.2 \%)\end{array}$ & 4.11 & 1.02 \\
\hline $\begin{array}{l}\text { Process of making decision } \\
\text { is moving too slowly. }\end{array}$ & $\begin{array}{c}18 \\
(40.0 \%)\end{array}$ & $\begin{array}{c}16 \\
(35.6 \%)\end{array}$ & $\begin{array}{c}6 \\
(13.3 \%)\end{array}$ & $\begin{array}{c}3 \\
(6.7 \%)\end{array}$ & $\begin{array}{c}2 \\
4.4 \%)\end{array}$ & 4.00 & 1.10 \\
\hline $\begin{array}{l}\text { Conflicts between } \\
\text { consultants and design } \\
\text { engineers that are late in } \\
\text { reviewing and approving } \\
\text { their work }\end{array}$ & $\begin{array}{c}18 \\
(40.0 \%)\end{array}$ & $\begin{array}{c}20 \\
(44.4 \%)\end{array}$ & $\begin{array}{c}2 \\
(4.4 \%)\end{array}$ & $\begin{array}{c}5 \\
(11.1 \%)\end{array}$ & $\begin{array}{c}0 \\
(0.0 \%)\end{array}$ & 4.13 & 0.94 \\
\hline $\begin{array}{l}\text { Having financial } \\
\text { difficulties (those are } \\
\text { delays in payment, } \\
\text { financial issues and } \\
\text { economic complications). }\end{array}$ & $\begin{array}{c}30 \\
(66.7 \%)\end{array}$ & $\begin{array}{c}5 \\
(11.1 \%)\end{array}$ & $\begin{array}{c}6 \\
(13.3 \%)\end{array}$ & $\begin{array}{c}4 \\
(8.9 \%)\end{array}$ & $\begin{array}{c}0 \\
(0.0 \%)\end{array}$ & 4.35 & 1.02 \\
\hline $\begin{array}{l}\text { Insufficient experience of } \\
\text { the consultants on site }\end{array}$ & $\begin{array}{c}25 \\
(55.6 \%)\end{array}$ & $\begin{array}{c}10 \\
(22.2 \%)\end{array}$ & $\begin{array}{c}2 \\
(4.4 \%)\end{array}$ & $\begin{array}{c}5 \\
(11.1 \%)\end{array}$ & $\begin{array}{c}3 \\
(6.7 \%)\end{array}$ & 4.08 & 1.29 \\
\hline $\begin{array}{l}\text { Other factors of } \\
\text { Inexcusable delay (please, } \\
\text { specify) }\end{array}$ & $\begin{array}{c}19 \\
(42.2 \%)\end{array}$ & $\begin{array}{c}15 \\
(11.1 \%)\end{array}$ & $\begin{array}{c}5 \\
(11.1 \%)\end{array}$ & $\begin{array}{c}3 \\
(6.7 \%)\end{array}$ & $\begin{array}{c}3 \\
(6.7 \%)\end{array}$ & 3.97 & 1.19 \\
\hline
\end{tabular}

Source: Field data, 2022 
The results in Table 1 show respondent's views on factors of inexcusable delays in Regional Cybercrime Center, almost all respondents agreed with the statement that there is delays in production of workshop drawings and sample tools whereby $44.4 \%$ of all responders strongly agreed and $31.1 \%$ of all responders also agreed. Furthermore, numerous responders agreed with the statement that delays caused by shortage in cooperation and communication in concerning parties whereby, $42.2 \%$ of all respondents strongly agreed and $40.0 \%$ of all respondents also agreed. Moreover, respondents confirm that process of making decision is moving too slowly whereby, $40.0 \%$ of all respondents responded with strongly agreed and $35.6 \%$ of all responders also responded agree. Numerous responders agreed with the statement that delays caused by conflicts between consultants and design engineers that are late in reviewing and approving their work whereby, $40.0 \%$ of all responders strongly agreed and $44.4 \%$ of all responders also agreed.

Besides, numerous responders agreed with the proclamation that having financial difficulties caused delays whereby, $66.7 \%$ of all responders strongly agreed and $11.1 \%$ of all responders also agreed. Besides, the majority of the respondents agreed with the statement that delays caused by insufficient experience of the consultants on site whereby $55.6 \%$ of all responders strongly agreed and $22.2 \%$ of all responders also agreed. As well, the majority of the responders agreed with the assertion that there are other factors of inexcusable delays whereby $42.2 \%$ of all responders strongly agreed and $11.1 \%$ of all responders also agreed. For descriptive statistics, High mean of 3.97 is a solid proof of the fact's existence and very high mean of 4.35 is a solid proof of the fact's existence while the lowest standard deviation was 0.94 and highest was 1.29 which indicate heterogeneity of responses.

One of the interviewed respondents stated that; "If Guangdong Haohe Engineering and Construction Company Limited, had not delayed in producing Geotechnical soil test results, timely planned on importation of raw materials and conducted a serious on site supervision the project would have met the set timelines. However, the delays affected the project budget which went way beyond $20 \%$ of the project value and thus forced the project manager to terminate the contract and sign a new contract with another construction company (Police Engineering Regiment)"

The findings are similar to Gündüz (2013) stated that inexcusable delays are solely as a result of the contactor and its supplier negligence. For this case, the contractor is not compensated and is required to either expedite the completion of the work or compensate the owner.

By considering majorities of respondents, verbal statement and scholars on factors of inexcusable delays, Researcher discovered that there were largely due to inconveniences of raw materials and engineers delay in reviewing and approving their work.

Table 2: Assessment of factors affecting cost overrun in Regional Cybercrime Center in Gasabo district, Rwanda

\begin{tabular}{lccccccc}
\hline Cost overrun & $\begin{array}{c}\text { Strongly } \\
\text { Agree (5) }\end{array}$ & $\begin{array}{c}\text { Agree } \\
(\mathbf{4})\end{array}$ & $\begin{array}{l}\text { Neutral } \\
(\mathbf{3})\end{array}$ & $\begin{array}{c}\text { Disagree } \\
\mathbf{( 4 )}\end{array}$ & $\begin{array}{c}\text { Strongly } \\
\text { Disagree (5) }\end{array}$ & Mean SD \\
\hline Lack of proper cost & 18 & 20 & 2 & 5 & 0 & & \\
management & $(40.0 \%)$ & $(44.4 \%)$ & $(4.4 \%)$ & $(11.1 \%)$ & $(0.0 \%)$ & 4.13 & 0.94 \\
Poor material & 30 & 5 & 6 & 4 & 0 & & \\
management & $(66.7 \%)$ & $(11.1 \%)$ & $(13.3 \%)$ & $(8.9 \%)$ & $(0.0 \%)$ & 4.35 & 1.02 \\
Inefficient design & 25 & 10 & 2 & 5 & 3 & 4.08 & 1.29 \\
\hline
\end{tabular}

Source: Field data, 2022 
The results in Table 2 showed that the majority of the responders agreed that lack of proper management affect cost overrun whereby $44.4 \%$ of all responders strongly agreed and $40.0 \%$ of all responders also agreed. The $66.7 \%$ of the respondents strongly agreed that poor material management affects cost overrun while $11.1 \%$ agreed. The 55-6\% of respondents strongly agreed while $22.2 \%$ agreed that inefficient design affects cost overrun. For descriptive statistics, high mean of 4.08 is a solid proof of the fact's existence and very high mean of 4.35 is a solid proof of the fact's existence while the lowest standard deviation was 0.94 and highest was 1.29 which indicate heterogeneity of responses which implies that lack of proper cost management, poor material management and inefficient design are the factors that affects cost overrun in Regional Cybercrime Center in Gasabo district, Rwanda.

Table 3: Correlation between inexcusable delays and project cost overrun

\begin{tabular}{|c|c|c|c|}
\hline & & Inexcusable delays & Project cost overrun \\
\hline \multirow{3}{*}{ Inexcusable delays } & Pearson correlation & 1 & $.773^{* *}$ \\
\hline & Sig. (2-tailed) & & .000 \\
\hline & $\mathrm{N}$ & 45 & 45 \\
\hline \multirow{3}{*}{ Project cost overrun } & Pearson correlation & $.773^{* *}$ & 1 \\
\hline & Sig. (2-tailed) & .000 & \\
\hline & $\mathrm{N}$ & 45 & 45 \\
\hline
\end{tabular}

Source: Field data, 2022

Correlation Table 3 shows p value of 0.000 , which is less than 0.05 and Pearson correlation of 0.797. This suggests that there is a link between responsible delays and the Regional Cybercrime Center's project excess cost. In concurrence with Singh (2010) investigated project delays and cost escalation in 894 projects across 17 infrastructure sectors. Delays, according to this study, are a major cause of cost overruns. Larger projects have had far greater cost overruns when in comparison to smaller projects.

Table 4: Model Summary between inexcusable delays and project cost overrun

\begin{tabular}{lcccc}
\hline Model & $\mathbf{R}$ & $\mathbf{R}^{\mathbf{2}}$ & Adjusted $\mathbf{R}^{\mathbf{2}}$ & Std. Error of the Estimate \\
\hline 1 & $.773^{\mathrm{a}}$ & .597 & .588 & 1.58587 \\
a. Predictors: (Constant), Inexcusable & delays & & \\
\hline
\end{tabular}

Source: Field data, 2022

Table 4 indicates the adjusted $\mathrm{R}^{2}$ in this study is 0.588 means that any change on project cost overrun is caused by the inexcusable delays at $58.8 \%$. This indicates that the model is acceptable, as the free figure moderately describes the dependent figure. In complement with Fugar and Baar (2010), Sambasivan and Soon (2007) have been done to ascertain the roots of delays; however, this study focuses on the implications or consequences that delays impose on construction companies in terms of their financial performance.

Table 5: ANOVA between inexcusable delays and project cost overrun

\begin{tabular}{|c|c|c|c|c|c|c|}
\hline Model & & $\Sigma$ of Squares & Df & Mean Square & $\mathbf{F}$ & Sig. \\
\hline & Regression & 160.434 & 1 & 160.434 & 63.792 & $.000^{\mathrm{b}}$ \\
\hline \multirow[t]{2}{*}{1} & Residual & 108.144 & 43 & 2.515 & & \\
\hline & Total & 268.578 & 44 & & & \\
\hline $\begin{array}{l}\text { a. Depe } \\
\text { b. Pred }\end{array}$ & $\begin{array}{l}\text { ndent Variab } \\
\text { ctors: (Const }\end{array}$ & $\begin{array}{l}\text { Project cost ove } \\
\text { Inexcusable }\end{array}$ & & & & \\
\hline
\end{tabular}

Source: Field data, 2022 
The entire model was significant, according to the results in Table 5. An estimated F statistic of 63.792 ( $\mathrm{p}$ value 0.05 ) indicated that the whole model was significant. The F statistics computed were higher than the essential F statistic. The results showed that the variable inexcusable delay is good predictor of project cost overrun; hereby the null hypothesis of the study is rejected. Similar to the study of Saleh and Abdul (2009) who stated construction delays are a critical component of construction projects and among the serious issues confronting Libyan construction firms. They identified the consequences of construction project delays, including authority blacklisting, stakeholder disengagement, reputational damage, financial and time waste.

\subsubsection{Non-compensable delays and project cost overrun}

The second specific objective was to determine the effect of non-compensable delays on the cost overrun of construction of Regional Cybercrime Center. Table 4.10, 4.11, 4.12 and 4.13 summarize the information regarding factors of non-compensable delays and its effects on cost overrun of Regional Cybercrime Center.

Table 6: Respondents views on factors of non-compensable delays

\begin{tabular}{|c|c|c|c|c|c|c|c|}
\hline Statements & $\begin{array}{l}\text { Strongly } \\
\text { Agree } \\
\text { (5) }\end{array}$ & $\begin{array}{l}\text { Agree } \\
\text { (4) }\end{array}$ & $\begin{array}{l}\text { Neutral } \\
\text { (3) }\end{array}$ & $\begin{array}{l}\text { Disagree } \\
\text { (2) }\end{array}$ & $\begin{array}{l}\text { Strongly } \\
\text { Disagree } \\
\text { (1) }\end{array}$ & Mean & $\begin{array}{l}\text { Std. } \\
\text { Dev. }\end{array}$ \\
\hline $\begin{array}{l}\text { Natural changes in } \\
\text { surrounding environment of } \\
\text { the construction site }\end{array}$ & $\begin{array}{c}16 \\
(35.6 \%)\end{array}$ & $\begin{array}{c}18 \\
(40.0 \%)\end{array}$ & $\begin{array}{c}6 \\
(13.3 \%)\end{array}$ & $\begin{array}{c}0 \\
(0.0 \%)\end{array}$ & $\begin{array}{c}5 \\
(11.1 \%)\end{array}$ & 3.88 & 1.22 \\
\hline $\begin{array}{l}\text { There has been a delay in } \\
\text { transportation. }\end{array}$ & $\begin{array}{c}27 \\
(60.0 \%)\end{array}$ & $\begin{array}{c}12 \\
(26.7 \%)\end{array}$ & $\begin{array}{c}1 \\
(2.2 \%)\end{array}$ & $\begin{array}{c}3 \\
(6.7 \%)\end{array}$ & $\begin{array}{c}2 \\
(4.4 \%)\end{array}$ & 4.31 & 1.10 \\
\hline Modifications to the contract & $\begin{array}{c}28 \\
(62.2 \%)\end{array}$ & $\begin{array}{c}9 \\
(20.0 \%)\end{array}$ & $\begin{array}{c}5 \\
(11.1 \%)\end{array}$ & $\begin{array}{c}2 \\
(4.4 \%)\end{array}$ & $\begin{array}{c}1 \\
(2.2 \%)\end{array}$ & 4.35 & 1.00 \\
\hline $\begin{array}{l}\text { Unrest in the workplace and } \\
\text { a strike }\end{array}$ & $\begin{array}{c}30 \\
(66.7 \%)\end{array}$ & $\begin{array}{c}12 \\
(26.7 \%)\end{array}$ & $\begin{array}{c}1 \\
(2.2 \%)\end{array}$ & $\begin{array}{c}0 \\
(0.0 \%)\end{array}$ & $\begin{array}{c}2 \\
(4.4 \%)\end{array}$ & 4.51 & 0.92 \\
\hline $\begin{array}{l}\text { Construction work has been } \\
\text { put on hold. }\end{array}$ & $\begin{array}{c}20 \\
(44.4 \%)\end{array}$ & $\begin{array}{c}17 \\
(37.8 \%)\end{array}$ & $\begin{array}{c}6 \\
(13.3 \%)\end{array}$ & $\begin{array}{c}0 \\
(0.0 \%)\end{array}$ & $\begin{array}{c}2 \\
(4.4 \%)\end{array}$ & 4.17 & 0.98 \\
\hline $\begin{array}{l}\text { Unplanned calamities (Fire, } \\
\text { wind, and snowfall) have all } \\
\text { had an impact on site } \\
\text { operations }\end{array}$ & $\begin{array}{c}22 \\
(48.9 \%)\end{array}$ & $\begin{array}{c}20 \\
(44.4 \%)\end{array}$ & $\begin{array}{c}2 \\
(4.4 \%)\end{array}$ & $\begin{array}{c}0 \\
(0.0 \%)\end{array}$ & $\begin{array}{c}1 \\
(2.2 \%)\end{array}$ & 4.37 & 0.77 \\
\hline $\begin{array}{l}\text { Other factors of non- } \\
\text { compensable delays }\end{array}$ & $\begin{array}{c}21 \\
(46.7 \%)\end{array}$ & $\begin{array}{c}16 \\
(35.6 \%)\end{array}$ & $\begin{array}{c}3 \\
(6.7 \%)\end{array}$ & $\begin{array}{c}0 \\
(0.0 \%)\end{array}$ & $\begin{array}{c}5 \\
(11.1 \%)\end{array}$ & 4.06 & 1.25 \\
\hline
\end{tabular}

\section{Source: Field data, 2022}

The results in Table 6 show respondent's views on factors of non-compensable delays in Regional Cybercrime Center, almost all respondents agreed with the statement that delays caused by natural changes in surrounding environment of the construction site whereby $35.6 \%$ of all responders strongly agreed and $40.0 \%$ of all responders also agreed. 
Furthermore, numerous responders agreed with the assertion that there has been a delay in transportation whereby, $60.0 \%$ of all respondents strongly agreed and $26.7 \%$ of all respondents also agreed. Moreover, respondents confirm that delays caused by modifications to the contract whereby, $62.2 \%$ of all respondents responded with strongly agreed and $20.0 \%$ of all respondents also responded agree.

Also, numerous responders agreed with the assertion that delays caused by unrest in the workplace and a strike whereby, $66.7 \%$ of all responders strongly agreed and $26.7 \%$ of all responders also agreed. Besides, majority of respondents agreed with the statement that delay due to construction work has been put on hold whereby, $44.4 \%$ of all responders strongly agreed and $37.8 \%$ of all responders also agreed. Besides, the majority of the responde nts agreed with the statement that delays caused by unplanned calamities (Fire, wind, and snowfall) have all had an impact on site operations whereby $48.9 \%$ of all responders strongly agreed and $44.4 \%$ of all responders also agreed.

Numerous responders agreed with the assertion that there are other factors related to noncompensable delays whereby $46.7 \%$ of all responders strongly agreed and $35.6 \%$ of all responders also agreed. For descriptive statistics, High mean of 3.88 is a significant proof of the fact's existence and very high mean of 4.51 is a significant proof of the fact's existence while the lowest standard deviation was 0.77 and highest was 1.25 which indicate heterogeneity of responses.

One of the respondents interviewed stated that; “..........among other factors, the outbreak of COVID-19 also contributed to construction delays of the Regional Cybercrime Center, since most of the materials used were imported from Asia specifically Japan, China and Singapore since the project is constructed under the Japanese Counterpart funds. The initial contract signed by Guangdong Haohe Engineering and Construction Co Ltd, a Singaporean Company",

The results agreed with Nuhu et al., (2017) mentioned that this type of delay is brought about by acts of God, unforeseen underground site conditions, force majeure and material shortages that exceed the expectations of construction parties at the time of contact agreement. Such delays include natural calamities, disasters and other unplanned events ori ginating from other actors like the state in its sovereign capacity.

Based on results from respondents' view, opinions on interviewee and scholars the factors related to non-compensable delays for construction projects during the period of the study include unplanned calamity of Covid-19 which has also affected estimated budget to be surplus.

Table 7: Correlation between non compensable delays and project cost overrun

\begin{tabular}{|c|c|c|c|}
\hline & & Non compensable delays & Cost overrun \\
\hline \multirow{4}{*}{$\begin{array}{l}\text { Non } \\
\text { delays }\end{array}$} & Pearson Correlation & 1 & $.657^{* *}$ \\
\hline & Sig. (2-tailed) & & .000 \\
\hline & $\mathrm{N}$ & 45 & 45 \\
\hline & Pearson correlation & $.657^{* *}$ & 1 \\
\hline \multirow[t]{2}{*}{ Project cost overrun } & Sig. (2-tailed) & .000 & \\
\hline & $\mathrm{N}$ & 45 & 45 \\
\hline
\end{tabular}

Source: Field data, 2022

Table 7 reveals that questionnaires were answered by 45 respondents. (Sig. $=0.000<0.05$, Pearson Correlation $=0.657$ ). This table indicates that non compensable delays have a significant moderate correlation with project cost overrun of Regional Cybercrime Center. The same to Kabila \& Mumba (2009) conducted a study in Zambian construction projects, 
cost overruns and delays are causes associated with inclement weather, environmental, scope changes, mitigation costs, protection, strikes, schedule delay, technical issues and inflation.

Table 8: Model Summary on non-compensable delays and project cost overrun

\begin{tabular}{|c|c|c|c|c|}
\hline Model & $\mathbf{R}$ & $\mathbf{R}^{2}$ & Adjusted $\mathbf{R}^{2}$ & $\begin{array}{l}\text { Std. Error of the } \\
\text { Estimate }\end{array}$ \\
\hline 1 & $.657^{\mathrm{a}}$ & .431 & .418 & 1.88494 \\
\hline
\end{tabular}

\section{Source: Field data, 2022}

Table 8 shows model summary, which indicates how well changes in non-compensable delays explained variations in project cost overrun. Adjusted R Square indicates that noncompensable delays have 41.8 percent of effect on project cost overrun of Regional Cybercrime Center. In complement with Abderisak (2015) mentioned delay has been especially apparent in large public building projects, where cost overruns and delays have been accepted as the norm. Because of the size and occurrence of these overruns, they have become substantial financial risks for clients as well contractors also having an influence on the project's performance.

Table 4.9: ANOVA between non-compensable delays and project cost overrun

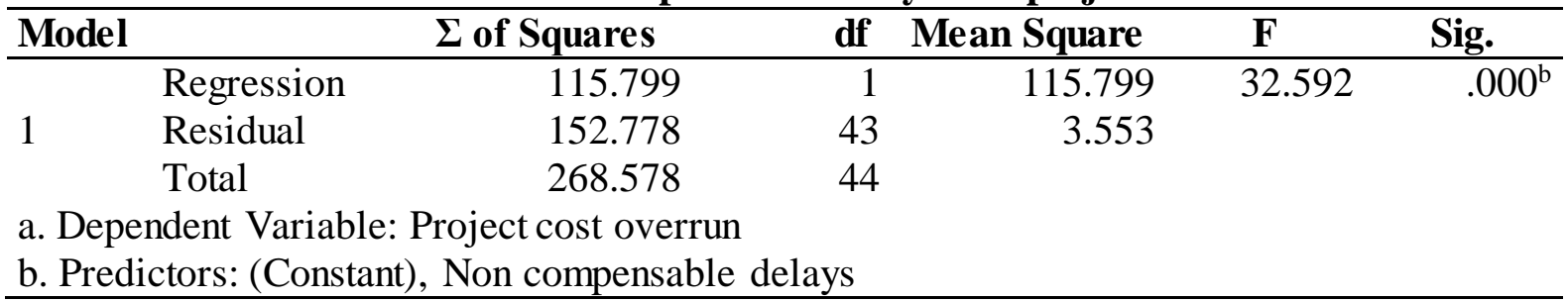

\section{Source: Field data, 2022}

Table 4.9 demonstrates that the overall model was significant as the entire The model was crucial. as $\mathrm{p}$ value was 0.000 lower to 0.05 . The findings indicate that non compensable delays are predictors of project cost overrun of Regional Cybercrime Center. Not far for LeHoai and Lee, (2008) revealed that labor cost, incorrect amount of departures and material cost increase from environmental constraints are the 3 common sources of cost overruns in Vietnam. 


\subsubsection{Compensable delays and project cost overrun}

Table 10: Respondents views on factors of compensable delays in Regional Cybercrime Center

\begin{tabular}{|c|c|c|c|c|c|c|c|}
\hline Statements & $\begin{array}{l}\text { Strongly } \\
\text { Agree } \\
\text { (5) }\end{array}$ & $\begin{array}{l}\text { Agree } \\
\text { (4) }\end{array}$ & $\begin{array}{l}\text { Neutral } \\
\text { (3) }\end{array}$ & $\begin{array}{l}\text { Disagree } \\
\text { (2) }\end{array}$ & $\begin{array}{l}\text { Strongly } \\
\text { Disagree } \\
\text { (1) }\end{array}$ & Mean & SD \\
\hline $\begin{array}{l}\text { Contractor's failure to } \\
\text { communicate with and } \\
\text { coordinate with other } \\
\text { parties is unacceptable }\end{array}$ & $\begin{array}{c}29 \\
(64.4 \%)\end{array}$ & $\begin{array}{c}10 \\
(22.2 \%)\end{array}$ & $\begin{array}{c}2 \\
(4.4 \%)\end{array}$ & $\begin{array}{c}1 \\
(2.2 \%)\end{array}$ & $\begin{array}{c}3 \\
(6.7 \%)\end{array}$ & 4.35 & 1.13 \\
\hline $\begin{array}{l}\text { Contractors' use of } \\
\text { substandard } \\
\text { construction methods is } \\
\text { a serious problem }\end{array}$ & $\begin{array}{c}17 \\
(37.8 \%)\end{array}$ & $\begin{array}{c}22 \\
(48.9 \%)\end{array}$ & $\begin{array}{c}4 \\
(8.9 \%)\end{array}$ & $\begin{array}{c}1 \\
(2.2 \%)\end{array}$ & $\begin{array}{c}1 \\
(2.2 \%)\end{array}$ & 4.17 & 0.86 \\
\hline $\begin{array}{l}\text { Rework as a result of a } \\
\text { clerical error during } \\
\text { construction }\end{array}$ & $\begin{array}{c}20 \\
(44.4 \%)\end{array}$ & $\begin{array}{c}15 \\
(33.3 \%)\end{array}$ & $\begin{array}{c}7 \\
(15.6 \%)\end{array}$ & $\begin{array}{c}1 \\
(2.2 \%)\end{array}$ & $\begin{array}{c}1 \\
(2.2 \%)\end{array}$ & 4.11 & 1.04 \\
\hline $\begin{array}{l}\text { Underestimation of } \\
\text { productivity, as well as } \\
\text { insufficient review } \\
\text { Low-skilled labor and }\end{array}$ & $\begin{array}{c}19 \\
(42.2 \%)\end{array}$ & $\begin{array}{c}18 \\
(40.0 \%)\end{array}$ & $\begin{array}{c}5 \\
(11.1 \%)\end{array}$ & $\begin{array}{c}1 \\
(2.2 \%)\end{array}$ & $\begin{array}{c}2 \\
(4.4 \%)\end{array}$ & 4.13 & 1.01 \\
\hline $\begin{array}{l}\text { lack of high technology } \\
\text { equipment }\end{array}$ & $\begin{array}{c}20 \\
(44.4 \%)\end{array}$ & $\begin{array}{c}21 \\
(46.7 \%)\end{array}$ & $\begin{array}{c}2 \\
(4.4 \%)\end{array}$ & $\begin{array}{c}0 \\
(0.0 \%)\end{array}$ & $\begin{array}{c}2 \\
(4.4 \%)\end{array}$ & 4.26 & 0.91 \\
\hline $\begin{array}{l}\text { Planning and scheduling } \\
\text { that is not up to par }\end{array}$ & $\begin{array}{c}31 \\
(68.9 \%)\end{array}$ & $\begin{array}{c}11 \\
(24.4 \%)\end{array}$ & $\begin{array}{c}1 \\
(2.2 \%)\end{array}$ & $\begin{array}{c}1 \\
(2.2 \%)\end{array}$ & $\begin{array}{c}1 \\
(2.2 \%)\end{array}$ & 4.55 & 0.84 \\
\hline $\begin{array}{l}\text { Other factors of } \\
\text { compensable delays }\end{array}$ & $\begin{array}{c}19 \\
(42.2 \%)\end{array}$ & $\begin{array}{c}18 \\
(40.0 \%)\end{array}$ & $\begin{array}{c}6 \\
(13.3 \%)\end{array}$ & $\begin{array}{c}0 \\
(0.0 \%)\end{array}$ & $\begin{array}{c}2 \\
(4.4 \%) \\
\end{array}$ & 4.15 & 0.97 \\
\hline
\end{tabular}

Source: Field data, 2022

The results in Table 10 show responders' views on factors of compensable delays in Regional Cybercrime Center, almost all respondents agreed with the statement that contractor's failure to communicate with and coordinate with other parties is unacceptable whereby $64.4 \%$ of all responders strongly agreed and $22.2 \%$ of all responders also agreed. Furthermore, the majority of the responders agreed with the assertion that contractors' use of substandard construction methods is a serious problem whereby $37.8 \%$ of all responders strongly agreed and $48.9 \%$ of all responders also agreed.

Moreover, respondents confirm that delays caused rework as a result of a clerical error during construction whereby, $44.4 \%$ of all respondents responded with strongly agreed and $33.3 \%$ of all respondents also responded agree. Also, numerous responders agreed with the assertion that delays caused by underestimation of productivity, as well as insufficient review whereby, $42.2 \%$ of all responders strongly agreed and $40.0 \%$ of all responders also agreed. Besides, majority of the respondents agreed with the statement that delays due to low-skilled labor and lack of high technology equipment whereby, $44.4 \%$ of all responders strongly agreed and $46.7 \%$ of all responders also agreed.

Besides, majority of the respondents agreed with the statement that delays caused by planning and scheduling that is not up to par whereby $68.9 \%$ of all responders strongly agreed and 
$24.4 \%$ of all responders also agreed. As well, numerous responders agreed with the assertion that there are other factors of compensable delays whereby $42.2 \%$ of all responders strongly agreed and $40.0 \%$ of all responders also agreed. For descriptive statistics, High mean of 4.11 is a significant proof of the fact's existence and very high mean of 4.55 is a strong evidence of the existence of the fact while the lowest standard deviation was 0.84 and highest was 1.13 which indicate heterogeneity of responses.

One of the respondents interviewed stated that; "This project delayed because the contractor was so reluctant on producing the architecture design, and was not releasing required funds on time......All these delays, coupled with the ever changing exchange rate of the Dollar, affected the project budget since the initial contract was signed in Dollar Currency. Had the contractor paid attention to these details, the project would probably have been completed on time"

The findings supported by Soon (2010) declared that this type of delay is demonstrated by proprietor's architect late release of drawings. Typically, a justifiable, compensable delay results in prolongation of schedule, exposing the proprietor to financial harms requested by contractor. In this instance, the contactor incurs further overheads associated with expanded field and home office costs as well as unabated home office costs.

Researcher revealed that compensable delays are among delays affected cost overrun of Regional Cybercrime Center as mentioned by majority of respondents and also confirmed by views from interviewed persons and in agreement with other scholars with the similar studies.

Table 11: Correlation between compensable delays and project cost overrun

\begin{tabular}{llrr}
\hline & Compensable delays & Project cost overrun \\
\hline & Pearson correlation & 1 & $.799^{* *}$ \\
Compensable delays & Sig. (2-tailed) & & .000 \\
& N & 45 & 45 \\
& Pearson correlation & $.799^{* *}$ & 1 \\
Project cost overrun & Sig. (2-tailed) & .000 & 45 \\
& N & 45 & \\
\hline
\end{tabular}

Source: Field data, 2022

According to Correlation Table 11, compensable delays strongly correlates with project cost overrun ( $\mathrm{r}=0.799$ with a p-value of 0.000 lower to 0.05 ). This shows that the linkage in compensable delays and project cost overrun of Regional Cybercrime Center is significant. In agreement with Amandin and Kule (2016). An open-ended questionnaire was used to analyze delays and cost overrun concerns in Rwanda's Gasabo District, one of 30 districts. They identified that the top 5 reasons of deferments for public building projects from 2012 to 2019 experienced delays in payment, material procurement, poor supervision, financial constraints on the part of client and contactors.

Table 12: Model Summary on compensable delays and project cost overrun

\begin{tabular}{lcccc}
\hline Model & $\mathbf{R}$ & $\mathbf{R}^{\mathbf{2}}$ & Adjusted $\mathbf{R}^{2}$ & Std. Error of the Estimate \\
\hline 1 & $.799^{\mathrm{a}}$ & .638 & .630 & 1.50348 \\
a. Predictors: (Constant), Compensable delays & & \\
\hline
\end{tabular}

Source: Field data, 2022

In Table 12, the model summary needed to display the coefficient of determination, shows how well changes in the independent variable explained variations in the dependent variable. Compensable delays have effect of $63.0 \%$ on cost overrun of Regional Cybercrime Center. 
Supported by Gasasira, Peter and Eugene (2016) in their study about determinants of cost overrun in Rwandan construction projects found that poor cost estimation, poor design, poor schedule management, slow decision making, problem in land acquisition poor contact management, delay in providing design and The primary reasons were a lack of soil investigation.

Table 13: ANOVA between compensable delays and project cost overrun

\begin{tabular}{|c|c|c|c|c|c|c|}
\hline Model & & $\Sigma$ of Squares & df & Mean Square & $\mathbf{F}$ & Sig. \\
\hline \multirow{3}{*}{1} & Regression & 171.379 & 1 & 171.379 & 75.816 & $.000^{\mathrm{b}}$ \\
\hline & Residual & 97.199 & 43 & 2.260 & & \\
\hline & Total & 268.578 & 44 & & & \\
\hline $\begin{array}{l}\text { a. Depe } \\
\text { b. Pred }\end{array}$ & $\begin{array}{l}\text { ndent Variab } \\
\text { ctors: (Cons }\end{array}$ & $\begin{array}{l}\text { Project cost ove } \\
\text { Compensable }\end{array}$ & & & & \\
\hline
\end{tabular}

\section{Source: Field data, 2022}

The results in Table 13 show that the model was significant overall. An estimated F statistic of 75.816 and a $p$ value of 0.000 indicated that the whole model was significant. The findings indicated that the compensable delays are predictor of project cost overrun. Hereby the null hypothesis of the study was rejected. In agreement with Kasimu (2012) focused on specific causes of construction projects delays such as insufficient coordination and improper communication between involved parties. This study was conducted using questionnaires for info gathering. The outcomes were reviewed using standard deviation and mean. Some factors included poor activity scheduling, inappropriate communication and design.

Table 14: Coefficients between compensable delays and project cost overrun

\begin{tabular}{|c|c|c|c|c|c|c|}
\hline \multirow{2}{*}{\multicolumn{2}{|c|}{ Model }} & \multicolumn{2}{|c|}{$\begin{array}{l}\text { Unstandardized } \\
\text { Coefficients }\end{array}$} & \multirow{2}{*}{$\begin{array}{c}\begin{array}{c}\text { Standardized } \\
\text { Coefficients }\end{array} \\
\text { Beta }\end{array}$} & \multirow[t]{2}{*}{$\mathbf{T}$} & \multirow[t]{2}{*}{ Sig. } \\
\hline & & $\mathrm{B}$ & Std. Error & & & \\
\hline & (Constant) & .343 & 5.690 & & .060 & .952 \\
\hline \multirow{3}{*}{1} & Inexcusable delays & .196 & .275 & .197 & .712 & .480 \\
\hline & Non compensable delays & .278 & .400 & .102 & .696 & .491 \\
\hline & Compensable delays & .445 & .254 & .535 & 1.752 & .087 \\
\hline
\end{tabular}

\section{Source: Field data, 2022}

The regression model $Y=\beta_{0}+\beta_{1} X_{1}+\beta_{2} X 2+\beta_{3} X_{3}+\varepsilon$ : $Y$ is Cost overrun, $X_{1}$ is the ine $x c$ usable delays, $\mathrm{X}_{2}$ is the non-compensable delays, $\mathrm{X}_{3}$ is compensable delays.

Table 4.14 revealed that there will always be a constant factor of 0.343 that determines cost overrun, according to the regression equation. For every unit increase in inexcusable delays, cost overrun increases by 0.196 , as clarified by the other figures. For every unit increase in non-compensable delays, cost overrun increases by 0.278 , as explained by the other variables. For every unit increase in compensable delays, cost overrun increases by 0.445 , as explained by the other variables.

\section{Hypothesis testing:}

$\mathrm{H}_{01}$ : Inexcusable delays have no statistically significant effect on cost overrun of construction of Regional Cybercrime Center. This hypothesis was tested by correlation analysis and regression. For the correlation coefficient of 0.773 and p-value of 0.00 this showed that correlation level is significant while adjusted R-square of 0.588 showed moderating effect 
and also analysis of variance found to be significant at lower to 0.005 . Thus, the first null hypothesis was rejected.

$\mathrm{H}_{02}$ : Non-compensable delays do not have statistically significant effect on cost overrun of construction of Regional Cybercrime Center. This hypothesis was tested by correlation analysis and regression. For the correlation coefficient of 0.657 and $p$ value of 0.00 this showed that correlation level is significant while adjusted $\mathrm{R}$-square of 0.418 showed weak effect and also analysis of variance found to be significant at less than 0.005. Thus, the second null hypothesis was rejected.

$\mathrm{H}_{03}$ : Compensable delays have no statistically significant effect on cost overrun of construction of Regional Cybercrime Center. This hypothesis was tested by correlation analysis and regression. For the correlation coefficient of 0.799 and $p$ value of 0.00 this showed that correlation level is significant while adjusted R-square of 0.630 showed moderating effect and also analysis of variance found to be significant at less than 0.005 . Thus, the third null hypothesis was rejected.

\subsection{Conclusion}

In conclusion, the first objective to assess effect of inexcusable delays on the cost overrun of construction of Regional Cybercrime Center, Findings of the study indicated that inexcusable delays have statistically significant effect on cost overrun of construction of Regional Cybercrime Center, Therefore the researcher rejected null hypothesis. The 2ndobjective was to assess the results of non-compensable delays on the cost overrun of construction of Regional Cybercrime Center, The results of this study directed that non-compensable delays have statistically significant effect on cost overrun of construction of Regional Cybercrime Center, hence the researcher had right to reject the second null hypothesis. The 3rd objective examined the impacts of compensable delays on the cost overrun of construction of Regional Cybercrime Center, statistical evidence revealed that there is significant effect of compensable delays on cost overrun of construction of Regional Cybercrime Center, hereby the third null hypothesis was rejected. From outcomes, the objectives were achieved and all null hypotheses were rejected, by saying that delay factors led to project cost overrun of construction projects based on data collected from respondents from Regional Cyber Crime Center.

\subsection{Recommendations}

The researcher would like to highlight the following recommendations basing on the findings of the study:

For project owners to achieve timely completion of construction projects without having to incur extra costs which lead to project cost overruns, financial resources (project budget) necessary to execute the project must be fully committed and set aside to avoid incongruities caused by delay in payments. The Government of Rwanda through the National Public Procurement Authority must impose heavy penalties on contractors who fail to meet project set timelines in order to discourage investors from inexcusable and compensable delay practices that can be avoided to enable the project meet the estimated schedule.

Conflicts between consultants and design engineers in late reviewing and approving of architect designs was found to be causing significant delay which in turn affects the project cost overruns. Project managers must ensure that, full consultations are made ahead of time to agree on the project design between the consultants, owners and site engineers to avoid such delays which affects project estimated budget. The contracting entity must conduct regular 
inspections on the project success so as to detect any possible delay on time. This will help the beneficiaries to address the problem before causing any financial and resource harm.

The study proved that, unplanned calamity such as COVID-19 was among the factors that caused delay and affected the estimated budget of the Regional Cybercrime Centre project in Rwanda National Police. For the Government project whether funded by the state or externally funded, factors such as force majeure must be included in contract drafting putting in place the foresighted measures to mitigate the damages caused. This will include determining the period of recovery and the role of parties involved in the recovery process.

Planning, scheduling and communication were among factors found that, caused significant delay in execution of the Regional Cybercrime Centre project. For RNP, to successfully achieve the construction set timelines and avoid extra unplanned costs, externally funded project contractors should fully communicate ahead of time on the planned sources of raw materials and other necessities in execution of the projects by assuring their availability, time of delivery and clear defined supply chain. Where possible, such raw materials should be imported or commitment to import the required raw materials clearly covered by the bank performance guarantee before the final notification of award of tender is issued.

\subsection{Acknowledgement}

I thank almighty God whose mercy, courage, power and gift of life accorded to me to move forward in my academic career. Firstly, my appreciations are extended to my lovely wife Betty Batamuriza and my Children, Ciana Irebe Amanya, Cuthbert Ishema Amanya and Kevin Gatera Amanya for never letting me down and for being always very special to me without you, achieving this would have remained a dream. I cannot do without expressing my heartfelt appreciation to my supervisor, Dr. Gitahi Njenga, whose generosity, sacrifice, time, energy and professional guidance kept me on track throughout the execution of this work. I appreciate his critical and timely constructive feedback. A big appreciation goes to my classmates, lecturers, and the administration of the Mount Kenya University for challenging me to move forward. Finally, I cannot do without a special recognition to the leadership of Rwanda National Police whose financial and moral support laid a firm foundation to my academic journey. I would also want to extend my appreciations to my respondents who have been the primary source of the information in this research. Thank you all for your kind contributions 


\section{References}

Abderisak, A. \& Goran, L. (2015). Implications of Cost Overruns and Time Delays on Major Public Construction Projects. Proceedings of the 19th International Symposium on Advancement of Construction Management and Real Estate, DOI: 10.1007/978-3662-46994-1_61

Amandin, M.M. \& Kule J.W. (2016). Project Delays on Cost Overrun Risks: A Study of Gasabo District Construction Projects Kigali, Rwanda. ABC Journal of Advanced Research, 5(1), 21-34. https://doi.org/10.18034/abcjar.v5i1.55

Bubshait, A.A. and Al-Juwait, Y.A. (2002). Factors contributing to construction costs in Saudi Arabia. Journal of Cost Engineering, 44(5): 30-34

Chandu, A.P., Marawar, D, S., Bhalerao, V.N. (2016). A methodology for ranking of causes of delay for residential Projects. International Research Journal of Engineering and Technology, 3(6), 224-231.

Enas, F. T. \& Pandey, R. K. (2013). Study of delay in project planning and design stages of civil engineering projects. International Journal of Engineering and Advanced Technology, 2(3), 456-461

Fugar F.D.K., \& Agyakwah, A.B. (2010). Delays in Building Construction Projects in Ghana. Australian Journal Construction Economy, $10 \quad$ (1): 128-141. https://doi.org/10.5130/ajceb.v10i1/2.1592

Gasasira I, Peter M, \& Eugene N. (2016). The causative factor leading to cost overrun in dam construction project in Rwanda: Case study Kinoni one dam construction project. European Journal of Business and Social Sciences. 4(11), 142-68.

Gündüz, M., Nielsen, Y., \& Özdemir, M. (2013). Quantification of Delay Factors Using the Relative Importance Index Method for Construction Projects in Turkey. Journal of Management in Engineering, 29(2), 133-139. https://doi.org/10.1061/(ASCE)ME.1943-5479.0000129

Henry A., Ruth, A., \& Dan, T. (2013). Investigation into the Causes of Delays and Cost Overruns in Uganda's Public Sector Construction Projects. Journal of Construction in Developing Countries, 18(2), 33-47.

Kaliba, C., Muya, M., \& Mumba, K. (2009). Cost escalation and schedule delays in road construction projects in Zambia. International Journal of Project Management, 27(5), 522-531. https://doi.org/10.1016/j.ijproman.2008.07.003

Kasimu, M. A., \& Abubakar, D. I. (2012). Causes of delay in Nigeria construction industry. Interdisciplinary Journal of Contemporary Research in Business, 4(2). 785-794.

Kwatsima, S. A. (2015). An investigation into the causes of delay in large construction projects in Kenya. Unpublished Mater thesis at Jomo Kenyatta University of agriculture and technology, Nairobi, Kenya. Retrieved on March 2, 2022 at http://hdl.handle.net/123456789/2424

Le-Hoai, L., Lee, Y.D., Lee, J.Y. (2008) Delay and cost overruns in Vietnam large construction projects: A comparison with other selected countries. KSCE Journal of Civil Engineering, 12(3), 367-377. https://doi.org/10.1007/s12205-008-0367-7

Ndundo F. N., Mbabazi M, Jaya S., \& Ephantus N. W. (2016). Institutional factors influencing timely completion of road project in Rwanda: Case of Government 
Externally Financed Projects. European Journal of Business and Social Sciences, 5(01): 146-59.

Nuhu B., Ibrahim A., Khalid A. \& Saud A. (2017). A Systematic Method to Analyze Force Majeure in Construction Claims. MDPI Journals 7(4):115. DOI: $10.3390 /$ buildings 7040115

Remon, F. A. (2013). Ranking of delay factors in construction projects after Egyptian revolution. Alexandria Engineering Journal, 52(3):387-406. https://doi.org/10.1016/j.aej.2013.03.002

Saleh A. T. \& Abdelnaser, O. (2009). Causes of delay in construction industry in Libya. The International Conference on Administration and Business. Bucharest, Romania

Sambasivan M. \& Soon Y. W. (2007). Causes and Effects of delays in Malaysian construction industry. International Journal of Project Management. 25(5): 517-526. https://doi.org/10.1016/j.ijproman.2006.11.007

Samson, Y. (2016). Investigation into road construction Project delays case of KCC and Agatare access roads. Unpublished master thesis at University of Rwanda, College of Science and Technology. Kigali, Rwanda

Singh, R. (2009). Delays and Cost Overruns in Infrastructure Projects: An Inquiry into Extents, Causes and Remedies. Unpublished research at Delhi School of Economics. Delhi, India.

Sweis, G., Sweis, R., Hammad, A.A \& Shboul, A. (2008). Delays in construction projects: The case of Jordan. International Journal of Project Management, 26 (8), 665674.https://doi.org/10.1016/j.ijproman.2007.09.009

Towhid P. \& Amiruddin I. (2012). Causes and Effects of delay in Iranian Construction projects. IACSIT International Journal of Engineering and Technology, 4(5), 598604. https://doi.org/10.7763/IJET.2012.V4.441 